BIBECHANA

Vol. 6, March 2010

\title{
DIVERSITY OF HERPETOFAUNA IN AND AROUND THE KOSHI TAPPU WILDLIFE RESERVE
}

\author{
Damodar Thapa Chhetry \\ P.G. Campus, Biratnagar, Tribhuvan University, Nepal
}

\begin{abstract}
The paper deals with the herpetofauna of Koshi Tappu Wildlife Reserve and its surroundings. A total of 23 species of herpetofauna belonging to 19 genera and 13 families were recorded. Of these 8 species belonging to 6 genera and 3 families were amphibians, and 15 species belonging to 13 genera and 10 families were reptiles.
\end{abstract}

\section{Keywords: herpetofauna.; Gavialis gangeticus; Koshi Tappu}

\section{Introduction}

The Koshi Tappu Wildlife Reserve is the first Ramsar site in Nepal. It extends between $86^{\circ} 55^{\prime}-87^{\circ} 05^{\prime} \mathrm{E}$ longitude and $26^{\circ} 34^{\prime}-26^{\circ} 45^{\prime} \mathrm{N}$ latitudes on the alluvial flood plain of the Sapta Koshi river which is fed by seven tributaries, the Indrawati , Bhote Koshi , Tama Koshi , Dudh Koshi , Liku , Arun and Tamor rivers. The reserve covers part of Sunsari, Saptari and Udayapur districts of the eastern development region. It is touched by twelve Village Development Committees. Eastern and western embankments of 5-7 m high were constructed by the Koshi dam project to control flood.

In and around of Koshi Tappu Wildlife Reserve are many notable wetlands like rivers, floodplain, Oxbow lakes and riverine marshes, fresh water marshes and ponds, seasonally flooded grassland, swamp forest, reservoir, paddy fields etc. These wetlands are the suitable habitat for the herpetofauna.

Several herpetologist have provided literature on herpetofauna of Nepal (Swan and Levition,1962; Dubois,1974; Nonhoe and Ouboter, 1987; Shah and Giri, 1992; Schleich, 1993; Shah, 1995; Schleich and Kaestle, 2002). However, Very few literature (Suwal,1993; WMI/IUCN,1994;) are available on herpetofauna of Koshi Tappu Wildlife Reserve and its surroundings.

\section{Materials and methods}

The herpetofauna was studied from July, 2002 to June, 2004, once in every month at regular interval from Koshi Tappu Wildlife and its surroundings. The amphibians were collected by the help of local people and fisher men. They used different materials like rubber glove, long iron tongue, different nets (Cast net, Scoop net etc.). The collected specimens were preserved in plastic containers in $10 \%$ formalin for further study.

In case of reptiles, long iron tongue, rubber glove, scoop net, plastic container etc. were mainly used for collection. Some of the collected specimens were preserved in $10 \%$ formalin for further study. Some reptiles were released after taking photographs. Informations about snakes were collected from local people. Reports about the presence of Gavialis gangeticus and Crocodylus palustris were also collected from local people. The collected specimens of amphibia 


\section{Damodar Thapa Chhetry}

and reptile were identified with standard literature (Stebbins, 1966; Cochran and Goin, 1970; Shrestha, 1981; Daniel, 1983; Conant and Collins, 1991; Das, 1991; Schleich, 1993; Murthy, 1995; Shrestha, 2001; and Schleich and Kaestle, 2002).

\section{Results and discussion}

The present study recorded altogether 23 species of herpetofauna belonging to 19 genera and 13 families. Of these 8 species belonging to 6 genera and 3 families were amphibians, and 15 species belonging to 13 genera and 10 families were reptiles (Table 1). Among the amphibians, 4 species were found commonly during the whole study period and 4 species were found rarely. Five species belonging to the ranidae family was observed. Among the ranidae species the Sphaerotheca breviceps was found rarely. But the family rhacophoridae and bufonidae included all rarely found species.

Among the reptiles, 5 species found commonly during the whole study period, 4 species found rarely and 6 species found rarely.

According to the local informations, the abundance of herpetofauna are in decreasing trend due to loss of habitat, poaching, killing and cosuming by people. Specially, the turtle species: Aspideretes hurum, Lissemys punctata, Pangshura flaviventer kill by local people for meat. Similarly, Python molurus molurus poach for leather. Naja naja is highly poisonous and the people kill this animal when they see.

\section{References}

1. D.M. Cochran and C.J. Goin, The New Field Book of Reptiles and Amphibians, Putnam Nature Field Book, New York (1970).

2. R. Conant and J. T. Collins, Field Guide to the Reptiles and Amphibians (1991).

3. J.C. Daniel, The Book of Indian Reptiles. Bombay Natural History Society, India (1983).

4. I. Das, Colour Guide to the Turtles and Tortoise of the Indian Sub continent. .A. Publishing Ltd., England (1991).5. A. Dubois, Diagnoses de troisespeces nouvelles d' Nepal. Bull. Zool. Soc. France 98(1974) 495.

6. Eastern and Central North America, 3rd Edition. Houghton Mifflin Co., Boston, Mass.

7. T.S.N. Murthy, Reptiles of India, R.R. Publishing Corporation, Delhi. (1995).

8. L.M.R. Nanhoe and P.E. Ouboter, The distribution of reptiles and amphibians in the AnnapurnaDhaulagiri region (Nepal). Zool. Verhandel. Leiden. Netherland 229(1987) 1.

9. H.H. Schleich, Contribution to the systematics and to a bibliography of the amphibians and reptiles from Nepal. J. Nepal Res. Centre 9(1993) 141.

10. H.H. Schleich and W. Kaestle, Amphibians and Reptiles of Nepal. Koeltz Scientific Books, Koenigstein (2002)

11. K.B. Shah, Enumeration of the Amphibians and Reptiles of Nepal. Publication No. 2. Department of National Parks and Wildlife Conservation, Ministry of Forest and Soil Conservation, Nepal (1995).

12. K.B. Shah and M. K. Giri, Some Amphibians and their local uses in Arun Basin. J. Nat. Hist. Mus. T.U., Nepal 12(1992) 9.

13. T.K. Shrestha, Distribution of amphibians of Nepal and their conservation. In: Introduction to Fauna and wildlife of Nepal. (Ed. Majupuria, T.C.) (1981) 148- 160, Lashkar, Kathmandu.

14. T.K. Shrestha, Herpetology of Nepal. Mrs. Bimala Shrestha, Kathmandu, Nepal (2001).

15. R.C. Stebbins, A Field Guide to Western Reptiles and Amphibians, Houghton Mifflin Co., Boston, Mass (1966) .

16. R. N. Suwal, Koshi Tappu Wildlife Reserve: Conservation Issues and Management Measures. A survey report submitted to IUCN, Nepal (1993).

17. L.W. Swan and A.E. Levition, The herpetology of Nepal: A history checklist and zoogeographical analysis of the herpetofauna. Proc. Calif. Acad. Sci., S San Francisco, USA 32(1962) 103. 
BIBECHANA

Vol. 6, March 2010

18. WMI/ IUCN- Nepal Biodiversity of Koshi Tappu Wildlife Reserve and its Adjacent Area. Applied Database for integrated Biodiversity Conservation in Nepal. Woodland Mountain Institute / IUCN - Nepal( 1994).

Herpetofauna in and around the Koshi Tappu Wildlife Reserve.

\begin{tabular}{|c|c|c|c|c|}
\hline Family & Scientific name & Common name & Local name & Local Status \\
\hline Ranidae & $\begin{array}{l}\text { Hoplobatrachus crassus } \\
\text { (Jerdon, 1853) }\end{array}$ & Jerdon's bull frog & Sandhe bhyaguto & $\begin{array}{l}\text { Commonly } \\
\text { found }\end{array}$ \\
\hline Ranidae & $\begin{array}{l}\text { Hoplobatrachus tigerinus } \\
\text { (Daudin,1802) }\end{array}$ & Indian bull frog & $\begin{array}{l}\text { Singare baghe } \\
\text { bhyaguto }\end{array}$ & , \\
\hline Ranidae & $\begin{array}{l}\text { Euphlyctis cyanophlyctis } \\
\text { (Schneider, 1799) }\end{array}$ & Skittering frog & Ahale bhyaguto & , \\
\hline Ranidae & $\begin{array}{l}\text { Limnonectes teraiensis } \\
\text { (Dubois, 1984) }\end{array}$ & Terai cricket frog & $\begin{array}{l}\text { Madhese kithre } \\
\text { bhyaguto. }\end{array}$ & , \\
\hline Ranidae & $\begin{array}{l}\text { Sphaerotheca breviceps } \\
\text { (Schneider,1799) }\end{array}$ & $\begin{array}{l}\text { Indian burrowing } \\
\text { frog. }\end{array}$ & $\begin{array}{l}\text { Bharati Khopilte } \\
\text { bhyaguto. }\end{array}$ & $\begin{array}{l}\text { Rarely } \\
\text { found }\end{array}$ \\
\hline Rhacophoridae & $\begin{array}{l}\text { Polypedates taeniatus } \\
\text { (Boulenger, 1906) }\end{array}$ & Terai tree frog & $\begin{array}{l}\text { Madhese singare } \\
\text { rukh bhyaguto }\end{array}$ & , \\
\hline Bufonidae & $\begin{array}{l}\text { Bufo melanostictus } \\
\text { (Schneider, 1799) }\end{array}$ & $\begin{array}{l}\text { Common Asian } \\
\text { toad }\end{array}$ & Khasre bhyaguto & , \\
\hline Bufonidae & $\begin{array}{l}\text { Bufo stomaticus (Lutken, } \\
\text { 1862) }\end{array}$ & Marbled toad & Khasre bhyguto & , \\
\hline Agamidae & $\begin{array}{l}\text { Calotes versicolor } \\
\text { (Daudin,1802) }\end{array}$ & $\begin{array}{l}\text { Common garden } \\
\text { lizard }\end{array}$ & Bagaiche chheparo & $\begin{array}{l}\text { Commonly } \\
\text { found }\end{array}$ \\
\hline Varanidae & $\begin{array}{l}\text { Varanus bengalensis } \\
\text { (Daudin, 1802) }\end{array}$ & Bengal monitor & Bhaise gohoro & $\begin{array}{l}\text { Very rarely } \\
\text { found }\end{array}$ \\
\hline Varanidae & $\begin{array}{l}\text { Varanus flavescens ( } \\
\text { Hardwicke and Gray, 1827) }\end{array}$ & Yellow monitor & Sun gohoro &, \\
\hline Colubridae & $\begin{array}{l}\text { Xenochrophis piscator } \\
\text { (Schneider, 1799) }\end{array}$ & $\begin{array}{l}\text { Checkered keel } \\
\text { back water snake }\end{array}$ & $\begin{array}{l}\text { Kothe dhodia } \\
\text { sarpa }\end{array}$ & $\begin{array}{l}\text { Commonly } \\
\text { found }\end{array}$ \\
\hline Colubridae & $\begin{array}{l}\text { Amphiesma stolatum } \\
\text { (Linnaeus, 1758) }\end{array}$ & $\begin{array}{l}\text { Buff-striped } \\
\text { keelback }\end{array}$ & Harara sarpa & , \\
\hline Elapidae & $\begin{array}{l}\text { Bungarus fasciatus } \\
\text { (Schneider, 1801) }\end{array}$ & Banded krait & $\begin{array}{l}\text { Pate gana guwali } \\
\text { sarpa }\end{array}$ & , \\
\hline Elapidae & $\begin{array}{l}\text { Bungarus caeruleus } \\
\text { (Schneider,1801) }\end{array}$ & $\begin{array}{l}\text { Common Indian } \\
\text { krait }\end{array}$ & Karet & , \\
\hline Elapidae & Naja naja (Linnaeus, 1758) & Spectacled cobra & Goman & $\begin{array}{l}\text { Very rarely } \\
\text { found }\end{array}$ \\
\hline Boidae & $\begin{array}{l}\text { Python molurus molurus } \\
\text { (Linnaeus, 1758) }\end{array}$ & Asiatic rock python & Ajingar & , \\
\hline Testudinidae & $\begin{array}{l}\text { Indotestudo elongata (Blyth, } \\
1853 \text { ) }\end{array}$ & Elongated tortoise & Kubadi kachhuwa & $\begin{array}{l}\text { Rarely } \\
\text { found }\end{array}$ \\
\hline Gavialidae & $\begin{array}{l}\text { Gavialis gangeticus (Gmelin, } \\
1789 \text { ) }\end{array}$ & Gharial & $\begin{array}{l}\text { Lamo thutune } \\
\text { gohi. }\end{array}$ & $\begin{array}{l}\text { Very rarely } \\
\text { found }\end{array}$ \\
\hline Crocodylidae & $\begin{array}{l}\text { Crocodylus palustris } \\
\text { (Lesson,1831) }\end{array}$ & Mugger crocodile & Magar gohi & , \\
\hline Trionychidae & $\begin{array}{l}\text { Aspideretes hurum } \\
\text { (Gray,1831) }\end{array}$ & $\begin{array}{l}\text { Indian peacock soft } \\
\text { shell turtle }\end{array}$ & $\begin{array}{l}\text { Naram khabate } \\
\text { kachhuwa }\end{array}$ & Rarely found \\
\hline Trionychidae & $\begin{array}{l}\text { Lissemys punctata } \\
\text { (Webb,1980) }\end{array}$ & $\begin{array}{l}\text { Indian flapshell } \\
\text { turtle }\end{array}$ & Putali kachhuwa &, \\
\hline Bataguridae & $\begin{array}{l}\text { Pangshura flaviventer } \\
\text { (Gunther,1864) }\end{array}$ & $\begin{array}{l}\text { Yellow-bellied tent } \\
\text { turtle. }\end{array}$ & $\begin{array}{l}\text { Pahelo bhude } \\
\text { dhuri kachhuwa }\end{array}$ & , \\
\hline
\end{tabular}

